\title{
Clinical Management of Community Acquired Pneumonia in the Elderly Patient
}

\section{Catia Cilloniz, Adrian Ceccato, Alicia San Jose \& Antoni Torres}

To cite this article: Catia Cilloniz, Adrian Ceccato, Alicia San Jose \& Antoni Torres (2016): Clinical Management of Community Acquired Pneumonia in the Elderly Patient, Expert Review of Respiratory Medicine, DOI: 10.1080/17476348.2016.1240037

To link to this article: http://dx.doi.org/10.1080/17476348.2016.1240037

Accepted author version posted online: 03

Oct 2016.

Submit your article to this journal $₫$

Q View related articles $\asymp$

View Crossmark data \lceil 
Publisher: Taylor \& Francis

Journal: Expert Review of Respiratory Medicine

DOI: $10.1080 / 17476348.2016 .1240037$

REVIEW

Clinical Management of Community Acquired Pneumonia in the Elderly Patient

$$
\text { Catia Cilloniz }{ }^{1} \text {, Adrian Ceccato }{ }^{2} \text {, Alicia San Jose }{ }^{3} \text {, Antoni Torres }{ }^{1}
$$

1.- Department of Pneumology, Institut Clinic del Tórax, Hospital Clinic of Barcelona Institut d'Investigacions Biomèdiques August $\mathrm{Pi}$ i Sunyer (IDIBAPS), University of Barcelona (UB) - SGR 911- Ciber de Enfermedades Respiratorias (Ciberes) Barcelona, Spain.

2.- Seccion Neumología, Hospital Nacional Alejandro Posadas, Palomar, Argentina.

3. - College of Nursing, University of Valladolid, Spain

\section{Corresponding author:}

Antoni Torres, MD

Department of Pneumology, Hospital Clinic of Barcelona, Spain

c/ Villarroel 170, 08036 Barcelona, Spain

Phone +34932275549

Fax +34932275549 


\section{Email: atorres@clinic.ub.es}

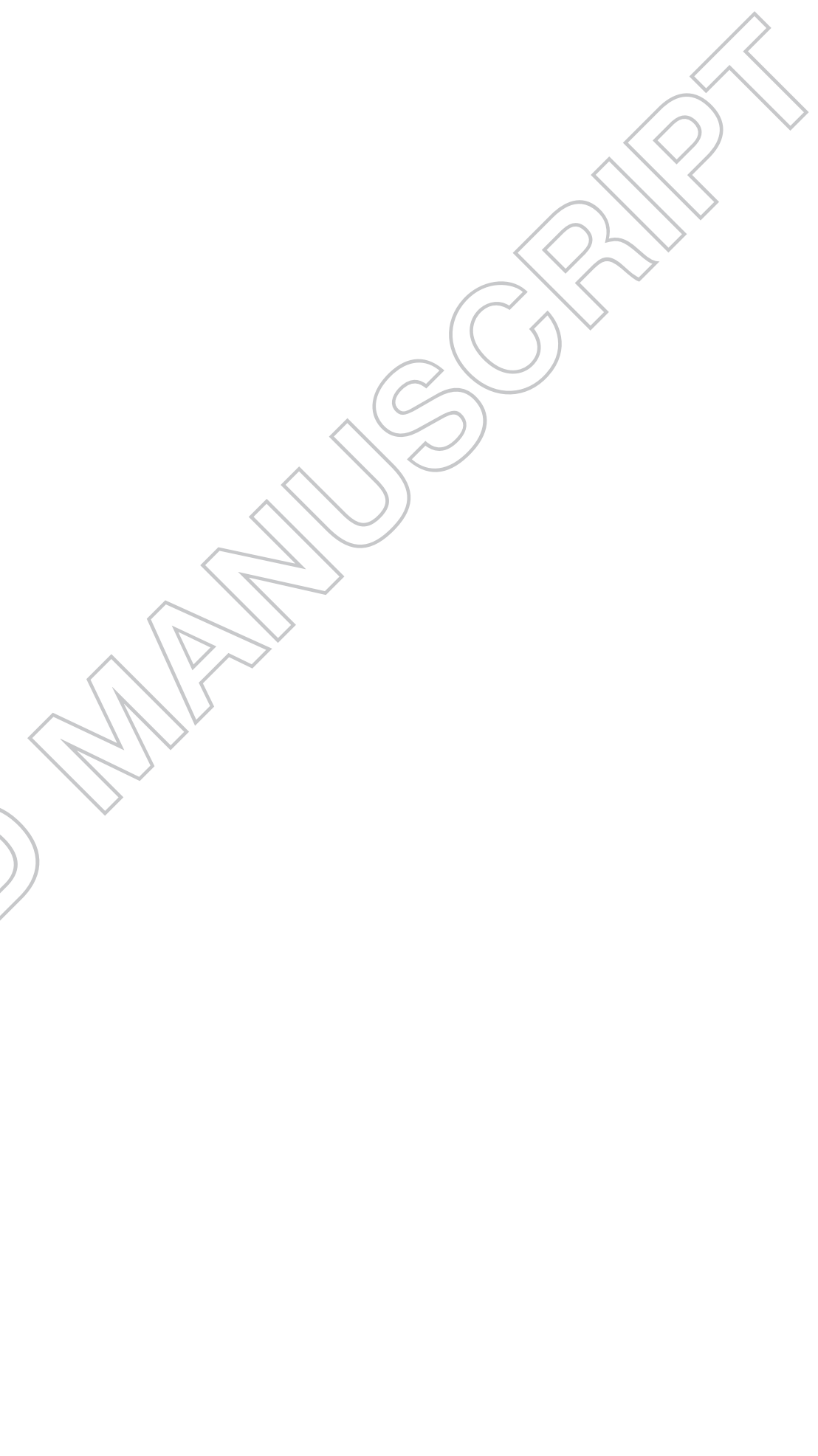




\section{Abstract}

Introduction: Community acquired pneumonia (CAP) is a major health problem in elderly persons and is associated with high morbidity and mortality.

Areas covered: This article reviews the most recent publications relative to CAP in the elderly population, with a focus on epidemiology, prognostic factors, microbial etiology, therapy and prevention. The data discussed in this review were mainly obtained from a non-systematic review using Medline, and references from relevant articles.

Expert Commentary: CAP can occur at any age, but its incidence and risk of death are linked to increasing age. Age-related changes in the immune system make this population more vulnerable to CAP. Mortality in hospitalized patients with CAP ranges from $10 \%$ to $12 \%$. However, in the case of elderly patients, several studies have reported mortality rates of up to $25 \%$. Pneumococcal and influenza vaccination comprise one of the most important preventive approaches for CAP in the elderly.

Keywords: community-acquired pneumonia; elderly; pneumonia 


\section{1. - INTRODUCTION}

Community-acquired pneumonia (CAP) is a serious health problem associated with high morbidity and mortality in all age groups worldwide[1]. In a recently published article on the incidence of CAP in a UK region, where 17, 316 cases of CAP were analyzed, the study reported that the incidence of CAP increased from $4.2 \%$ /year between 1998 and 2008 to 8.8\%/year between 2009 and 2014[2]. In 2013, The Global Burden of Disease Study found that lower respiratory tract Infections (LRTI) were the second cause of death, based on data from 188 countries around the world [3]. In Europe, the mortality rates for CAP vary widely from country to country, ranging from $<1 \%$ to $48 \%[4]$.

CAP can occur at any age, but its incidence and risk of death are linked to increasing age [5-7]. Older age is an important risk factor for pneumonia and is associated with elevated morbidity and mortality due to the physiological changes associated with aging and a greater presence of chronic disease. The incidence of CAP in patients over the age of 65 years accounts for 25 to 35 cases per 1000 inhabitants/year [6-8]. A study by Cillóniz et al on microbial etiology of CAP by comorbidity found that age does not significantly affect pathogen patterns; however, the main factors associated with mortality were neurologic diseases, the presence of a potential MDR pathogen, and very advanced age ( $>85$ years) [5].

There is a strong association between advanced age and the decline in the integrity of physical barriers, protection against invading pathogens, and age-related changes in the immune system, which make this population vulnerable to CAP, and clinicians should pay close attention to this entity due to increased life expectancy in the coming years. 


\section{2. - Age-Related Changes in the Immune System}

The human lung has an effective and complex defense against respiratory infections. Impairment of mucociliary clearance (that prevents attachment of bacteria to the epithelium), impairment of alveolar defense, ineffective cough, and swallowing disorders are altered lung mechanisms of defense in elderly patients[11].

Immunological changes that occur with age involving decreased efficiency of the adaptive and innate immune systems are called "Immunosenescence". Immunosenescence is known to be responsible for the increased susceptibility of the host to infectious diseases and limited response to vaccines[9]. Consequences of immunosenescence in patients with CAP include the risk of misdiagnosis in this population because some specific symptoms of infection such as cough, fever, and leukocyte count do not reflect the real state of elderly patients with pneumonia[10]. Figures 1 and 2 show age-related changes to the adaptive and innate immune system in elderly persons.

\section{3. - Epidemiology}

The global population is currently aging rapidly. According to 2015 data from the United Nations World Population Prospects, the world population reached 7.3 billion in mid-2015. This data reported that, in 2015, there were 901 million people aged 60 or over, comprising $12 \%$ of the global population. The population aged 60 or over was growing at a rate of $3.26 \%$ per year. By 2050 , in all major areas of the world except Africa, it is expected that nearly a quarter or more of the population will be aged 60 years or over. The number of older persons in the world is projected to reach 1.4 billion by 2030 and 2.1 billion by 2050 , and could rise to 3.2 billion by $2100[12]$. 
The study by Jain et al[13] found an increased incidence of hospitalized CAP with increasing age. The annual incidence of pneumonia was 24.8 cases per 10,000 adults, with the highest rates among adults between 65 and 79 years of age (63.0 cases per 10,000 adults) and those 80 years of age or older (164.3 cases per 10,000 adults). A Germany study by Ewig et al[14] on the impact of age and comorbidities on the etiology of hospitalized CAP patients, including 2,049 patients, reported that age does not influence the microbial cause itself, but the mortality rate increased with age (6574 years, 6.9\%; 75-84 years, $8.9 \%$; $>85$ years, $17.1 \%$; $P<.001)$.

The economic cost related to CAP remains high. A recently published Dutch study that included 195,372 CAP cases reported that the median costs of CAP case were dependent on age and type of care, with costs ranging from €344 (€482) per episode for 0-9 year olds treated as outpatients, to $€ 10,284(€ 16,374)$ per episode for $50-64$ year olds admitted to the ICU. In this study the majority of CAP episodes (64\%) and costs (76\%) occurred among patients aged over 50 years [15].

Mortality in hospitalized patients with CAP ranges from $10 \%$ to $12 \%$. However, in the case of elderly patients, several studies reported that mortality rates can reach up to $25 \%[[6 ; 16 ; 17]$. A recently published study examining the impact of age and comorbidities on mortality in a cohort of 6,205 patients with CAP suggests that patients aged $\geq 80$ years, instead of $\geq 65$ years, should be considered a risk factor for poor outcome[18].

\section{4. - Interactions Between Age and Comorbidities}

Elderly persons suffer from a variety of chronic diseases; these comorbidities will affect the integrity of host resistance to infections with the consequence that they are exposed to increased risk of morbidity and mortality. The immune dysfunction 
associated with aging is responsible for the reduced response to infection and increased pathological disorders in the elderly population.

In $80 \%$ of the CAP cases in the study by Cilloniz et al[5] on the impact of age and comorbidities on the etiology of pneumonia, at least one comorbidity (chronic respiratory disease, diabetes mellitus, chronic cardiovascular disease, neurological disease, chronic liver disease, and chronic renal disease) was present at the following rates by age group: $65-74$ yrs, $77.6 \% ; 75-84$ yrs, $80.6 \%$; and $\geq 85$ yrs, $80.8 \%$. The most frequent comorbidity in all age groups in this study was chronic pulmonary disease (54.1\%). COPD was the most frequent respiratory comorbidity decreasing in frequency with age[5].

Recently, a study by Kofteridis et al[19] of diabetes mellitus 2 in elderly CAP patients showed that elderly patients with diabetes mellitus, despite initial lower CURB65 scores, required longer hospitalization and had worse outcomes compared with patients without diabetes mellitus 2.

There are several risk factors for pneumonia in elderly patients. Jackson et al[20] identified cardiopulmonary comorbidities, weight loss, and the presence of functional or cognitive impairments as independent risk factors for pneumonia.

\section{5. - Microbial Etiology}

Microbiological diagnosis in CAP constantly decreased with each age group, as reported by Cilloniz et al[5] in a study that analyzed microbial etiology by age group in a cohort of 2,149 CAP patients. Microbiological diagnosis was as follows: $65-74$ years, $43.7 \%$; 75-84 years, $40.7 \%$; and $\geq 85$ years, $31.4 \%(p<0.001)$.

In several worldwide clinical studies on the microbial etiology of CAP in elderly patients, including nursing-home patients, Streptococcus pneumoniae (pneumococcus) 
remains the most frequent pathogen in CAP[5;21;22]. A Spanish study [5] on the impact of age and comorbidities on the etiology of CAP in a population of 2,149 patients, excluding nursing home cases and which categorized the population in 3 age groups ( 65 to 74 years; 75 to 84 years; > 85 years) reported that age does not influence microbial etiology by itself. Streptococcus pneumoniae was the most frequent pathogen reported in all age groups $(40.7 \%, 39.4 \%$, and $48.9 \%$, respectively), followed by mixed etiology $(16.0 \%, 13.1 \%$, and $10.6 \%)$, atypical pathogens $(16.0 \%, 13.1 \%$, and 9.9\%), and respiratory viruses $(8.4 \%, 14.6 \%$, and $11.3 \%)$. In patients where at least one comorbidity was present, Haemophilus influenzae was the most common pathogen, and multidrug-resistant pathogens (MDR) were common in patients with one or more comorbidities. However, a recently published study by Jain et al[13] in 2,480 hospitalized patients with CAP reported that respiratory viruses (human rhinovirus and influenza virus) are the most frequent pathogens (15\%) in this population, followed by pneumonia due to $S$ pneumoniae $(5 \%)$. The study concluded that the incidence increased with age for each pathogen.

An interesting study carried out in the United States [23] on the distribution of pneumococcal serotypes in patients over 50 years of age by using urine antigen detection (UAD) assay capable of detecting 13-valent pneumococcal conjugate vaccine (PCV13) associated serotypes reported that PCV13 associated serotypes were identified in $11 \%$ of pneumococcal CAP cases and 7-valent pneumococcal conjugate vaccine (PCV7) serotypes were identified in $25 \%$ of cases. The study concluded that pneumococcal serotypes causing non-invasive pneumonia in adults may differ significantly from those causing invasive disease. 
The most frequent respiratory viruses in the elderly population are influenza virus and respiratory syncytial virus, which cause high morbidity and mortality. There are many reports of epidemic outbreaks, especially in nursing home patients. It has also been reported that respiratory viruses may not only cause viral pneumonia but are also associated with bacterial infection (polymicrobial CAP); the most frequent bacterial pathogens associated with respiratory viruses are $S$ pneumoniae, $S$ aureus, and $H$ influenzae [24-26].

Several studies have reported a low rate of MDR in the elderly population and the most frequently reported pathogens were methicillin-resistant Staphylococcus aureus (MRSA) and gram-negative bacteria (Haemophilus influenzae, Pseudomonas aeruginosa, Klebsiella pneumoniae, etc). Elderly patients are a population susceptible to admission to a nursing home residence, and differences regarding etiology have been reported from different parts of the world. In Europe, two reports on nursing homes showed similar etiology to that reported in community-acquired pneumonia $[21 ; 27]$.

In elderly patients, clinicians should carefully consider the presence of specific risk factors associated with MDR pathogens, such as prior antibiotic therapy [28;29], chronic pulmonary disease[5;29], admission to a nursing home [22;30], and prior hospitalization.

\section{6. - Clinical Presentation and Diagnosis of CAP}

Clinical presentation of pneumonia in elderly patients may be different from that of the general adult population; in general, the more common symptoms associated with pneumonia in elderly persons are falls and altered mental status, fatigue, lethargy, delirium, anorexia, tachypnea, tachycardia, and, less commonly, pleuritic pain, cough, 
fever, and leukocytosis[10;31]. Since most elderly patients present with one or more comorbidities, pneumonia sometimes presents as an exacerbation or decompensation of these comorbidities (Figure 3). A chest x-ray is required to confirm pneumonia. However, in this special population, radiographic findings are not conclusive or are confusing in approximately $30 \%$ of cases[1;32]. A study by Haga et al[33] on the diagnostic utility of computed tomography compared to chest $\mathrm{x}$-ray in the diagnosis and evaluation of pneumonia severity in elderly patients showed that approximately $10 \%$ of CT-determined pneumonic infiltration was overlooked by chest $x$-ray based diagnosis. The authors demonstrated that CT was superior to chest $\mathrm{x}$-ray for diagnosing and evaluating the severity of CAP in elderly patients.

More recently, the study by Ticinesi et al[34], which compared the accuracy of lung ultrasound and standard chest x-ray for the diagnosis of pneumonia in 169 older patients, showed that diagnosis accuracy for pneumonia was significantly higher in lung ultrasound compared with standard chest x-ray, with better sensitivity and negative predictive value.

Some diseases and syndromes have clinical signs and symptoms that can mimic pneumonia in elderly patients. In adults over 65 years old, the incidence of tuberculosis is higher than in other age groups with the exception of the HIV-infected population[35]. Clinicians should be taken into account the fact that, in nursing home patients, the incidence of tuberculosis is approximately 3 times higher than in patients living in the community. We should also remember that the elderly population is a reservoir of tuberculosis and should suspect this entity, which may be misdiagnosed as bacterial pneumonia[10;35]. 
Worldwide data show that the percentage of people living with HIV at an advanced age (50 years and above) has increase in the last decade. In elderly patients, HIV infection is often discovered by opportunistic pulmonary infections that mimic pneumonia[36].

Congestive heart failure in elderly patients presenting at the emergency department with respiratory symptoms and suspicion of pneumonia is a frequent entity, as chronic cardiovascular disease is a frequent comorbidity in this population[5]. In these cases, the use of biomarkers such as procalcitonin measurement will help identify patients with bacterial infection and guide antibiotic therapy. Elderly patients with congestive heart failure and elevated procalcitonin levels suggest bacterial infection[37;38].

\section{7. - Prognostic Factors (Figure 4)}

A recently published study by Akirov et al[39] on the prognostic value of glucose levels in elderly patients with pneumonia, in a cohort of 2,164 elderly patients, showed that, in elderly non-diabetic patients hospitalized for pneumonia, moderate and markedly elevated blood glucose levels on admission were associated with increased short-term and long-term mortality.

Neupane et al[40], in a study of predictive factors of in-hospital mortality and rehospitalization in 717 enrolled older CAP patients, reported that chronic comorbidities are the main predictor of death and re-hospitalization in older patients with CAP, while vitamin E supplementation was protective.

A recently published study by Luna et al[18] on the impact of age and comorbidities on the mortality of different age groups with CAP found that the presence of comorbidities is associated with poor outcome in CAP patients. The study also 
reported that age $\geq 80$ years is a factor for increased mortality when patients presented less than 1 comorbidity.

Several scores exist to predict 30-day mortality and admission to the ICU. In these scores, age is an important factor.

The scores most widely used to predict mortality are PSI [41] and CURB65[42]; the former was developed by Fine et al and includes 21 variables, among which age has considerable weight. In the validation cohort, the people in higher categories (IV, V) were elderly (median, 75 years old) and were not assigned to this category due to their age alone. In the PSI, nursing home residence increases the risk of 30 -day mortality. The CURB65 is a score that includes 5 variables, one of which is age 65 years or older. These useful scores are easy to use and include variables that are widely available. In a recent study, Luna et al[18] observed that age did not add to mortality in CAP until 80 years old if only 1 comorbidity or no comorbidities were present; furthermore, there are significant differences in the simplified CRB-65 between patients under 65 years old, those aged 65 to 79 years, and those over 80 years.

Chen et al[43] evaluated the performance of these two scores in a young, elderly and very old population, and found the worst performance of the scores, mainly in PSI, in the elderly and very old population. This may be due an overestimated weight of age. The author proposed a modified score excluding age in this population.

Among the scores for predicting admission to the ICU, need for vasoactive drugs, or need for mechanical ventilation, the most commonly used are the SMART-COP[44] and the score proposed by ATS/IDSA guidelines[1]. Age is not present in the ATS/IDSA guidelines and in the SMART-COP, the cutoff for age was 50 years. 
Physicians should pay particular attention to specific factors of this population that may predict a poor outcome, such as previous bed confinement, abnormal mental status, absence of chills, or nutritional status[45;46].

To predict treatment failure, a composite outcome associated with mortality, several risk factors have been described by Menendez et al[47]. Independent risk factors include liver disease, PSI score, leukopenia, multilobar pneumonia, pleural effusion, and radiological signs of cavitation. Independent factors associated with a lower risk of treatment failure were influenza vaccination, initial treatment with fluoroquinolones, and chronic obstructive pulmonary disease (COPD). Age is not present among these variables but elderly patients are more likely to present these factors, leading to a higher PSI score, as described above.

\section{8.- Treatment}

The cornerstone in the treatment of pneumonia is antibiotic treatment. Empirical treatment may vary in accordance with different guidelines; however, the main guidelines recommend empirical treatment for severe pneumonia that covers $S$ pneumoniae and atypical germs such as $L$ pneumophila, $M$ pneumoniae and Chlamydia species[1;48]. The most widely used empirical treatment is $\beta$-lactam with inhibitor of beta lactamase or $3^{\text {rd }}$ generation cephalosporins plus a macrolide, or a respiratory fluoroquinolone (Figure 5). The benefit of combination therapy with macrolides over other antibiotic treatment is the subject of debate. According to retrospective analysesand non-interventional studies, macrolide combination therapy reduces mortality, mainly in patients with severe pneumonia[49-51]. Macrolides have an immunomodulatory effect in the lung and their benefits in the treatment of pulmonary disease go beyond the antimicrobial effect [52], and they have proven benefits in non- 
infectious pulmonary disease such as cystic fibrosis [53], COPD[54], and bronchiectasis[55]. In recent studies, therapy with $\beta$-lactams alone show noninferiority in 90-day mortality [56] compared to a combination of $\beta$-lactams plus macrolides or fluoroquinolones; however, these studies were carried out in patients not admitted to the ICU. In another prospective study, therapy with $\beta$-lactams alone did not show non-inferiority in the proportion of patients who reached clinical stability by day $7[57]$.

In 2005, the ATS/IDSA introduced a new concept, "health care associated pneumonia", a heterogeneous population with a risk of higher mortality and germs with multidrug resistance [1]. This population included patients residing in nursing homes. In two European cohorts, we observed that etiology in nursing home acquired pneumonia, did not differ from that observed in community acquired pneumonia not requiring broad-spectrum antibiotics[21;27]. To calculate the risk of multidrug-resistant germs, we developed a score to detect PES ( $P$ aeruginosa, extended-spectrum $\beta$-lactamase [ESBL]) Enterobacteriaceae, and MRSA pathogens in CAP patients aged between 40 and 65 years, where male sex scored 1 point, age $>65$ years, prior antibiotic treatment, chronic respiratory disease, and consciousness impairment scored 2 points, and chronic renal failure scored 3 points. One point is reduced when patients present fever in the emergency room. In this score, patients with 5 points or higher had a risk of PES pathogen. Belonging to the elderly population was included as a risk factor in this score[29]. 


\section{9. - Adjunctive Treatments}

The mortality associated with CAP remains high despite appropriate antibiotic treatment [58] and for this reason, adjunctive therapies are becoming a major subject of study. A retrospective non-interventional study described a benefit for statins, angiotensin-converting enzyme, and angiotensin II receptor blocker in different outcomes in patients with CAP[59]. These drugs are commonly used by elderly patients with cardiovascular disease. A meta-analysis found evidence that elderly patients treated with angiotensin-converting enzyme and, to a lesser extent, angiotensin II receptor blocker, had lower rates of hospitalization for CAP; further prospective studies should be performed to evaluate the benefits of these drugs[60]. In the case of statins, recent prospective studies evaluating statins in CAP found no evidence to suggest that statin use before and during hospitalization improved outcomes in CAP $[61 ; 62]$.

In severe CAP, high levels of inflammatory cytokines can be harmful and can cause pulmonary dysfunction associated with adverse outcomes. Corticosteroids are the most widely used anti-inflammatory drugs and have been shown to be effective at reducing treatment failure in patients with severe pneumonia and higher inflammatory response[63], and reducing the time to clinical stability by 1.4 days, length of stay by 1 day, and time on intravenous antibiotics by 1 day [64], according to two recent randomized controlled trials. The benefits of corticosteroids in CAP were also observed in two recent meta-analyses, where a benefit was found regarding the risk of ARDS, need for mechanical ventilation, and reduced length of stay; disagreement persists regarding mortality. Corticosteroids did not increase adverse effects[65;66]. 


\section{0. - Outcomes}

In-hospital mortality or 30-day mortality in hospitalized elderly patients with CAP ranges from $8 \%$ to $17 \%[5 ; 14 ; 67]$. Advanced age is known to be associated with high risk of long-term mortality. Mortality at 6 months was reported to be $19 \%$ and mortality at 1 year was 41\%[67;68].

A study by Mortensen et al[69] analyzed 1555 CAP patients and assessed long-term mortality; the study reported that comorbid conditions (reflected by the Charlson comorbidity score), age, and nursing home residence were the strongest predictors of long-term mortality in CAP. Similarly, a study by Johnstone et al[70] on long-term morbidity and mortality reported that long-term morbidity and mortality are high following hospitalization for pneumonia and are strongly correlated with initial PSI class.

A systematic review by Prescott et al[71] on diagnosis of early and late readmission after hospitalization for CAP reported that early readmission (30 days) was more frequent in the elderly population ( $\geq 65$ years) than in the general adult population.

\section{1. - Prevention}

In elderly persons, immunosenescence is the main cause of insufficient protection following vaccination. The weak and low antibody response in elderly people is the principal problem. International guidelines $[1 ; 72]$ recommend specific measures to prevent pneumonia. The most important of these is the use of pneumococcal vaccines (polysaccharide and conjugated) and influenza vaccines in all older adults and for 
younger persons with medical conditions that place them at a high risk of pneumonia morbidity and mortality.

\subsection{ACIP Recommendations 2015 for PCV13 and PPV23 in Adults [73;74]}

- Pneumococcal vaccine in naïve persons $\geq 65$ years: naïve persons should receive a single dose of PCV13 first, followed by a dose of PPV23 $\geq 1$ year later.

- Prior vaccination with PPV23 at age $\geq 65$ years: adults aged $\geq 65$ years who have previously received $\geq 1$ doses of PPV23 should also-receive a dose of PCV13 if they have not yet received it. A dose of PCV13 should be given $\geq 1$ year after receipt of the most recent PPV23 dose. In the case of patients who need repeating PPV23, the period between received PCV13 and the new dose of PPV23 should be $\geq 1$ year, and 5 years after the most recent dose of PPV23.

- ACIP recommendations for immunocompromised patients remain unchanged[75].

- The recommendations for routine PCV13 use among adults aged $\geq 65$ years will be re-evaluated in 2018 and revised as needed.

\section{2. - Future Directions}

CAP in the elderly is an important health problem worldwide, as the global population is currently aging rapidly. In future clinical practice, combined specialist teams will be required for the management of elderly patients with pneumonia (pulmonary specialist, infectious diseases and geriatric specialists) in order to improve the management of patients. More clinical research is needed in order to provide more complete information to help with the management of pneumonia in this specific population. Research into rehabilitation of elderly patients after CAP episodes will 
prevent physical dysfunction. Furthermore, future studies are needed to identify several indices for predicting overall mortality in different patient categories. More research on the use of corticosteroids in elderly patients with severe pneumonia is needed. It is also necessary to identify immunological biomarkers that help in the early detection of infection, the level of immune competence and mortality risk. National and International guidelines should be implemented based on current knowledge of pneumonia in the elderly in order to disseminate these research data worldwide.

\section{3. - Conclusion}

Community-acquired pneumonia in the elderly person is associated with high health costs, a high rate of readmission, and high mortality. Because the clinical presentation of pneumonia in elderly persons may be different from younger adults, clinicians should suspect pneumonia in older persons who have an atypical presentation in order to avoid complications associated with delayed treatment. 


\section{4. - Expert Commentary}

Because the global population is currently aging rapidly, the incidence of pneumonia in the elderly population is increasing. Pneumonia in the elderly is more likely to be severe, as a large proportion of patients suffer from comorbidities that complicate pneumonia presentation.

In several worldwide clinical studies on the microbial etiology of CAP in elderly patients, including nursing-home patients, Streptococcus pneumoniae remains the most frequent pathogen in CAP. In elderly patients, clinicians should carefully consider the presence of specific risk factors associated with MDR pathogens, such as prior antibiotic therapy, chronic pulmonary disease, consciousness impairment, chronic renal failure, and prior hospitalization.

In general, the more common symptoms associated with pneumonia in elderly persons are falls and altered mental status, fatigue, lethargy, delirium, anorexia, tachypnea, tachycardia, and, less commonly, pleuritic pain, cough, fever, and leukocytosis. Since most elderly patients present with one or more comorbidities, pneumonia sometimes presents as an exacerbation or decompensation of these comorbidities.

The scores most widely used to predict mortality are PSI and CURB65. These scores perform worse in the elderly population due to the excess weight of age in the scores. Different cutoffs may improve the accuracy of severity scores in this population.

Antimicrobial therapy for elderly patients is the same as for the general population; however, clinicians must take into account the presence of risk factors for multiresistant pathogens. Patients receiving combination therapy with macrolides may have a better outcome. A retrospective study demonstrated the safety of macrolide use in the elderly population in terms of cardiovascular adverse events. 
Therapy with corticosteroids has been shown to be effective at reducing treatment failure in patients with severe pneumonia and higher inflammatory response, reducing time to clinical stability and length of stay.

Some studies described a benefit of statins, angiotensin-converting enzyme, and angiotensin II receptor blocker in different outcomes in patients with CAP, further prospective studies should evaluated the use of these drugs in CAP.

In-hospital mortality or 30-day mortality in hospitalized elderly patients with CAP ranges from $8 \%$ to $17 \%$. Also advanced age is associated with high risk of long-term mortality. Early and late readmission after hospitalization for CAP is frequent in elderly patients.

Vaccination is one of the most important preventive approaches for CAP in the elderly.

\section{5. - Five-Year view}

Development of new rapid microbiological tests will reduce the time to etiological diagnosis and help with prompt adequate antimicrobial therapy, thereby reducing the use of broad-spectrum antibiotics.

New or modified severity scores are necessary to improve the clinical management of CAP in elderly patients.

Further studies should evaluate the efficacy of adjunctive therapy with statins, angiotensin-converting enzyme, and angiotensin II receptor blocker in CAP in the elderly.

Surveillance of etiological pathogens may improve vaccination policy in the elderly population. 


\section{6. - Key Issues}

- Community-acquired pneumonia (CAP) remains an important infection and cause for hospitalization in the elderly population.

- Incidences of pneumonia increase with age and are associated with a high health cost.

- The clinical presentation of pneumonia in the elderly differs from the general population and is a major challenge for clinicians.

- Streptococcus pneumoniae is the main pathogen reported in this population. However, we should be cautious with patients with risk factors for multiresistant pathogens.

- Pneumococcal and influenza vaccination comprise one of the most important preventive approaches for CAP in the elderly.

\section{Funding}

This paper was not funded.

\section{Declaration of Interest}

A. Ceccato has taken part in an ERS long-term fellowship. C. Cillóniz has taken part in an ERS short-term fellowship The authors have no other relevant affiliations or financial involvement with any organization or entity with a financial interest in or financial conflict with the subject matter or materials discussed in the manuscript apart from those disclosed. 
1. Mandell LA, Wunderink RG, Anzueto A, Bartlett JG, Campbell GD, Dean NC, Dowell SF, File TM, Jr., Musher DM, Niederman MS, Torres A, Whitney CG: Infectious Diseases Society of America/American Thoracic Society consensus guidelines on the management of community-acquired pneumonia in adults. Clin Infect.Dis. 2007, 44 Suppl 2:S27-S72.

2. Quan TP, Fawcett NJ, Wrightson JM, Finney J, Wyllie D, Jeffery K, Jones N, Shine B, Clarke L, Crook D, Walker AS, Peto TE: Increasing burden of community-acquired pneumonia leading to hospitalisation, 1998-2014. Thorax 2016, 71:535-542.

3. GBD 2013 Mortality and Causes of Death Collaborators.: Global, regional, and national age-sex specific all-cause and cause-specific mortality for 240 causes of death, 1990-2013: a systematic analysis for the Global Burden of Disease Study 2013. Lancet 2015, 385:117-171.

4. Welte T, Torres A, Nathwani D: Clinical and economic burden of community-acquired pneumonia among adults in Europe. Thorax 2012, 67:71-79.

5. Cilloniz C, Polverino E, Ewig S, Aliberti S, Gabarrus A, Menendez R, Mensa J, Blasi $\mathrm{F}$, Torres A: Impact of age and comorbidity on cause and outcome in community-acquired pneumonia. Chest 2013, 144:999-1007.

6. Ochoa-Gondar O, Vila-Corcoles A, de DC, Arija V, Maxenchs M, Grive M, Martin E, Pinyol JL: The burden of community-acquired pneumonia in the elderly: the Spanish EVAN-65 study. BMC.Public Health 2008, 8:222.

7. Vila-Corcoles A, Ochoa-Gondar O, Rodriguez-Blanco T, Raga-Luria X, Gomez-Bertomeu F. Epidemiology of community-acquired pneumonia in older adults: a population-based study. Respir.Med. 2009, 103:309-316.

8. Kaplan V, Angus DC, Griffin MF, Clermont G, Scott WR, Linde-Zwirble WT: Hospitalized community-acquired pneumonia in the elderly: age- and sexrelated patterns of care and outcome in the United States. Am.J.Respir.Crit Care Med. 2002, 165:766-772.

9. Weiskopf D, Weinberger B, Grubeck-Loebenstein B: The aging of the immune system. Transpl.Int. 2009, 22:1041-1050.

10. Janssens JP: Pneumonia in the elderly (geriatric) population. Curr.Opin.Pulm.Med. 2005, 11:226-230.

11. Speert DP: Bacterial infections of the lung in normal and immunodeficient patients. Novartis.Found.Symp. 2006, 279:42-51.

12. United Nations Department of Economic and Social Affairs/Population Division. World Population Prospects: The 2015 Revision Volume II: Demographic Profiles. 2015.

Ref Type: Report 
13. Jain S, Self WH, Wunderink RG, Fakhran S, Balk R, Bramley AM, Reed C, Grijalva CG, Anderson EJ, Courtney DM, Chappell JD, Qi C, Hart EM, Carroll F, Trabue C, Donnelly HK, Williams DJ, Zhu Y, Arnold SR, Ampofo K, Waterer GW, Levine M, Lindstrom S, Winchell JM, Katz JM, Erdman D, Schneider E, Hicks LA, McCullers JA, Pavia AT, Edwards KM, Finelli L: Community-Acquired Pneumonia Requiring Hospitalization among U.S. Adults. N.Engl.J Med. 2015, 373:415-427.

14. Ewig S, Birkner N, Strauss R, Schaefer E, Pauletzki J, Bischoff H, Schraeder P, Welte T, Hoeffken G: New perspectives on community-acquired pneumonia in 388406 patients. Results from a nationwide mandatory performance measurement programme in healthcare quality. Thorax 2009, 64:1062-1069.

15. Rozenbaum MH, Mangen MJ, Huijts SM, van der Werf TS, Postma MJ: Incidence, direct costs and duration of hospitalization of patients hospitalized with community acquired pneumonia: A nationwide retrospective claims database analysis. Vaccine 2015, 33:3193-3199.

16. Klausen HH, Petersen J, Lindhardt T, Bandholm T, Hendriksen C, Kehlet H, Vestbo J, Andersen O: Outcomes in elderly Danish citizens admitted with community-acquired pneumonia. Regional differencties, in a public healthcare system. Respir.Med. 2012, 106:1778-1787.

17. Eurich DT, Marrie TJ, Minhas-Sandhu JK, Majumdar SR: Ten-Year Mortality after Community-acquired Pneumonia. A Prospective Cohort. Am.J.Respir.Crit Care Med. 2015, 192:597-604.

18. Luna CM, Palma I, Niederman MS, Membriani E, Giovini V, Wiemken TL, Peyrani P, Ramirez J: The Impact of Age and Comorbidities on the Mortality of Patients of Different Age Groups Admitted with Community-Acquired Pneumonia. Ann.Am, Thorac.Soc. 2016.

19. Kofteridis DP, Giourgouli G, Plataki MN, Andrianaki AM, Maraki S, Papadakis JA, Zacharioudaki ME, Samonis G: Community-Acquired Pneumonia in Elderly Adults with Type 2 Diabetes Mellitus. J.Am.Geriatr.Soc. 2016, 64:649-651.

20. Jackson ML, Nelson JC, Jackson LA: Risk factors for community-acquired pneumonia in immunocompetent seniors. J.Am.Geriatr.Soc. 2009, 57:882888.

21. Polverino E, Dambrava P, Cilloniz C, Balasso V, Marcos MA, Esquinas C, Mensa J, Ewig S, Torres A: Nursing home-acquired pneumonia: a 10 year single-centre experience. Thorax 2010, 65:354-359.

22. El Solh AA, Sikka P, Ramadan F, Davies J: Etiology of severe pneumonia in the very elderly. Am.J.Respir.Crit Care Med. 2001, 163:645-651.

23. Sherwin RL, Gray S, Alexander R, McGovern PC, Graepel J, Pride MW, Purdy J, Paradiso P, File TM, Jr.: Distribution of 13-valent pneumococcal conjugate vaccine Streptococcus pneumoniae serotypes in US adults aged $>/=50$ years with community-acquired pneumonia. J.Infect.Dis. 2013, 208:1813-1820. 
24. Angeles MM, Camps M, Pumarola T, Antonio MJ, Martinez E, Mensa J, Garcia E, Penarroja G, Dambrava P, Casas I, Jimenez de Anta MT, Torres A: The role of viruses in the aetiology of community-acquired pneumonia in adults. Antivir.Ther. 2006, 11:351-359.

25. Rocha Neto OG, Leite RF, Baldi BG: Update on viral community-acquired pneumonia. Rev.Assoc.Med.Bras. 2013, 59:78-84.

26. Burk M, El-Kersh K, Saad M, Wiemken T, Ramirez J, Cavallazzi R: Viral infection in community-acquired pneumonia: a systematic review and meta-analysis. Eur.Respir.Rev. 2016, 25:178-188.

27. Ewig S, Klapdor B, Pletz MW, Rohde G, Schutte H, Schaberg T, Bauer TT, Welte T: Nursing-home-acquired pneumonia in Germany: an 8-year prospective multicentre study. Thorax 2011, 67:132-138.

28. Cilloniz C, Gabarrus A, Ferrer M, Puig de la BJ, Rinaudo M, Mensa J, Niederman MS, Torres A: Community-Acquired Pneumonia due to Multidrug and non-Multidrug resistant Pseudomonas aeruginosa. Chest 2016, Apr 6. pii: S0012-3692(16)47572-0. doi: 10.1016/j.chest.2016.03.042. [Epub ahead of print].

29. Prina E, Ranzani OT, Polverino E, Cilloniz C, Ferrer M, Fernandez L, Puig de la $\mathrm{BJ}$, Menendez R, Mensa J, Torres A: Risk factors associated with potentially antibiotic-resistant pathogens in community-acquired pneumonia. Ann.Am.Thorac.Soc. 2015, 12:153-160.

30. Aliberti S, Zanaboni AM, Blasi F: Pneumonia in the community caused by multidrug-resistant organisms: keep working on probabilistic scores. Clin.Infect.Dis. 2012, 54:1519-1520.

31. Faverio P, Aliberti S, Bellelli G, Suigo G, Lonni S, Pesci A, Restrepo MI: The management of community-acquired pneumonia in the elderly. Eur.J.Intern.Med. 2014, 25:312-319.

32. Basi SK, Marrie TJ, Huang JQ, Majumdar SR: Patients admitted to hospital with suspected pneumonia and normal chest radiographs: epidemiology, microbiology, and outcomes. Am.J.Med. 2004, 117:305-311.

33. Haga T, Fukuoka M, Morita M, Cho K, Tatsumi K: Computed Tomography for the Diagnosis and Evaluation of the Severity of Community-acquired Pneumonia in the Elderly. Intern.Med. 2016, 55:437-441.

34. Ticinesi A, Lauretani F, Nouvenne A, Mori G, Chiussi G, Maggio M, Meschi T: Lung ultrasound and chest $x$-ray for detecting pneumonia in an acute geriatric ward. Medicine (Baltimore) 2016, 95:e4153.

35. Negin J, Abimbola S, Marais BJ: Tuberculosis among older adults--time to take notice. Int.J.Infect.Dis. 2015, 32:135-137.

36. Mpondo BC: HIV Infection in the Elderly: Arising Challenges. J.Aging Res. 2016, 2016:2404857. 
37. Demissei BG, Valente MA, Cleland JG, O'Connor CM, Metra M, Ponikowski P, Teerlink JR, Cotter G, Davison B, Givertz MM, Bloomfield DM, Dittrich H, van der MP, van Veldhuisen DJ, Hillege HL, Voors AA: Optimizing clinical use of biomarkers in high-risk acute heart failure patients. Eur.J.Heart Fail. 2016, 18:269-280.

38. Demissei BG, Cleland JG, O'Connor CM, Metra M, Ponikowski P, Teerlink JR, Davison B, Givertz MM, Bloomfield DM, Dittrich H, van Veldhuisen DJ, Hillege HL, Voors AA, Cotter G: Procalcitonin-based indication of bacterial infection identifies high risk acute heart failure patients. Int.J.Cardiol. 2016, 204:164-171.

39. Akirov A, Shimon I: The prognostic significance of admission blood glucose levels in elderly patients with pneumonia (GAP Study). J.Diabetes Complications 2016, 30:845-851.

40. Neupane B, Walter SD, Krueger P, Marrie T, Loeb M: Predictors of inhospital mortality and re-hospitalization in older adults with community-acquired pneumonia: a prospective cohort study. BMC.Geriatr. 2010, 10:22.

41. Fine MJ, Auble TE, Yealy DM, Hanusa BH, Weissfeld LA, Singer DE, Coley CM, Marrie TJ, Kapoor WN: A prediction rule to identify low-risk patients with community-acquired pneumonia. N Engl JMed 1997, 336:243-250.

42. Lim WS, van der Eerden MM, Laing R, Boersma WG, Karalus N, Town GI, Lewis SA, Macfarlane JT: Defining community acquired pneumonia severity on presentation to hospital: an international derivation and validation study. Thorax 2003, 58:377-382.

43. Chen JH, Chang SS, Liu JJ, Chan RC, Wu JY, Wang WC, Lee SH, Lee CC: Comparison of clinical characteristics and performance of pneumonia severity score and CURB-65 among younger adults, elderly and very old subjects. Thorax 2010, 65:971-977.

44. Charles PG, Wolfe R, Whitby M, Fine MJ, Fuller AJ, Stirling R, Wright AA, Ramirez JA, Christiansen KJ, Waterer GW, Pierce RJ, Armstrong JG, Korman TM, Holmes P, Obrosky DS, Peyrani P, Johnson B, Hooy M, Grayson ML: SMART-COP: a tool for predicting the need for intensive respiratory or vasopressor support in community-acquired pneumonia. Clin.Infect.Dis. 2008, 47:375-384.

45. Riquelme R, Torres A, El-Ebiary M, Mensa J, Estruch R, Ruiz M, Angrill J, Soler N: Community-acquired pneumonia in the elderly. clinical and nutritional aspects. Am J Respir Crit Care Med 1997, 156:1908-1914.

46. Zalacain R, Camino J, Cabriada V: [Pneumonia in the elderly]. Arch.Bronconeumol. 1998, 34 Suppl 2:63-67.

47. Menendez R, Torres A, Zalacain R, Aspa J, Martin Villasclaras JJ, Borderias L, Benitez Moya JM, Ruiz-Manzano J, Rodriguez de Castro F, Blanquer J, Perez D, Puzo C, Sanchez GF, Gallardo J, Alvarez C, Molinos L: Risk factors of 
treatment failure in community acquired pneumonia: implications for disease outcome. Thorax 2004, 59:960-965.

48. Woodhead M, Blasi F, Ewig S, Garau J, Huchon G, Ieven M, Ortqvist A, Schaberg T, Torres A, van der HG, Read R, Verheij TJ: Guidelines for the management of adult lower respiratory tract infections--full version. Clin.Microbiol.Infect. 2011, 17 Suppl 6:E1-59.

49. Mortensen EM, Halm EA, Pugh MJ, Copeland LA, Metersky M, Fine MJ, Johnson CS, Alvarez CA, Frei CR, Good C, Restrepo MI, Downs JR, Anzueto A: Association of azithromycin with mortality and cardiovascular events among older patients hospitalized with pneumonia. JAMA 2014, 311:21992208.

50. Asadi L, Sligl WI, Eurich DT, Colmers IN, Tjosvold L, Marrie TJ, Majumdar SR: Macrolide-based regimens and mortality in hospitalized patients with community-acquired pneumonia: a systematic review and meta-analysis. Clin.Infect.Dis. 2012, 55:371-380.

51. Restrepo MI, Mortensen EM, Waterer GW, Wunderink RG, Coalson JJ, Anzueto A: Impact of macrolide therapy on mortality for patients with severe sepsis due to pneumonia. Eur.Respir.J. 2009, 33:153-159.

52. Kovaleva A, Remmelts HH, Rijkers GT, Hoepelman AI, Biesma DH, Oosterheert JJ: Immunomodulatory effects of macrolides during communityacquired pneumonia: a literature review. J.Antimicrob.Chemother. 2012, 67:530-540.

53. Saiman L, Anstead M, Mayer-Hamblett N, Lands LC, Kloster M, HocevarTrnka J, Goss CH, Rose LM, Burns JL, Marshall BC, Ratjen F: Effect of azithromycin on pulmonary function in patients with cystic fibrosis uninfected with Pseudomonas aeruginosa: a randomized controlled trial. JAMA 2010,303:1707-1715.

54. Albert RK, Connett J, Bailey WC, Casaburi R, Cooper JA, Jr., Criner GJ, Curtis JL, Dransfield MT, Han MK, Lazarus SC, Make B, Marchetti N, Martinez FJ, Madinger NE, McEvoy C, Niewoehner DE, Porsasz J, Price CS, Reilly J, Scanlon PD, Sciurba FC, Scharf SM, Washko GR, Woodruff PG, Anthonisen NR: Azithromycin for prevention of exacerbations of COPD. N.Engl.J.Med. 2011, 365:689-698.

55. Wong C, Jayaram L, Karalus N, Eaton T, Tong C, Hockey H, Milne D, Fergusson W, Tuffery C, Sexton P, Storey L, Ashton T: Azithromycin for prevention of exacerbations in non-cystic fibrosis bronchiectasis (EMBRACE): a randomised, double-blind, placebo-controlled trial. Lancet 2012, 380:660-667.

56. Postma DF, van Werkhoven $\mathrm{CH}$, van Elden LJ, Thijsen SF, Hoepelman AI, Kluytmans JA, Boersma WG, Compaijen CJ, van der WE, Prins JM, Oosterheert JJ, Bonten MJ: Antibiotic treatment strategies for communityacquired pneumonia in adults. N.Engl.J.Med. 2015, 372:1312-1323. 
57. Garin N, Genne D, Carballo S, Chuard C, Eich G, Hugli O, Lamy O, Nendaz M, Petignat PA, Perneger T, Rutschmann O, Seravalli L, Harbarth S, Perrier A: beta-Lactam Monotherapy vs beta-Lactam-Macrolide Combination Treatment in Moderately Severe Community-Acquired Pneumonia: A Randomized Noninferiority Trial. JAMA Intern.Med. 2014, 174:1894-1901.

58. Shindo Y, Ito R, Kobayashi D, Ando M, Ichikawa M, Goto Y, Fukui Y, Iwaki M, Okumura J, Yamaguchi I, Yagi T, Tanikawa Y, Sugino Y, Shindoh J, Ogasawara T, Nomura F, Saka H, Yamamoto M, Taniguchi H, Suzuki R, Saito $\mathrm{H}$, Kawamura T, Hasegawa Y: Risk factors for 30-day mortality in patients with pneumonia who receive appropriate initial antibiotics: an observational cohort study. Lancet Infect.Dis. 2015.

59. Mortensen EM, Nakashima B, Cornell J, Copeland LA, Pugh MJ, Anzueto A, Good C, Restrepo MI, Downs JR, Frei CR, Fine MJ: Population-based study of statins, angiotensin II receptor blockers, and angiotensin-converting enzyme inhibitors on pneumonia-related outcomes. Clin.Infect.Dis. 2012, 55:1466-1473.

60. Shah S, McArthur E, Farag A, Nartey M, Fleet JL, Knoll GA, Kim SJ, Garg AX, Jain AK: Risk of hospitalization for community acquired pneumonia with renin-angiotensin blockade in elderly patients: a population-based study. PLoS.One. 2014, 9:e110165.

61. Viasus D, Garcia-Vidal C, Simonetti AF, Dorca J, Llopis F, Mestre M, Morandeira-Rego $\mathrm{F}$, Carratala $\mathrm{J}$ : The effect of simvastatin on inflammatory cytokines in community-acquired pneumonia: a randomised, double-blind, placebo-controlled trial. BMJ Open. 2015, 5:e006251.

62. Havers F, Bramley AM, Finelli L, Reed C, Self WH, Trabue C, Fakhran S, Balk R, Courtney DM, Girard TD, Anderson EJ, Grijalva CG, Edwards KM, Wunderink RG, Jain S: Statin Use and Hospital Length of Stay Among Adults Hospitalized With Community-acquired Pneumonia. Clin.Infect.Dis. 2016, 62:1471-1478.

63. Torres A, Sibila O, Ferrer, Polverino, Menendez R, Mensa J, Gabarrus A, Sellares J, Restrepo M, Anzueto A, Niederman MS, Agusti. Effect of Corticosteroids on Treatment Failure among Hospitalized Patients with Severe Community-Acquired Pneumonia and High Inflammatory Response: a Randomized Clinical Trial. JAMA . 15 A.D. Ref Type: Generic

64. Blum CA, Nigro N, Briel M, Schuetz P, Ullmer E, Suter-Widmer I, Winzeler B, Bingisser R, Elsaesser H, Drozdov D, Arici B, Urwyler SA, Refardt J, Tarr P, Wirz S, Thomann R, Baumgartner C, Duplain H, Burki D, Zimmerli W, Rodondi N, Mueller B, Christ-Crain M: Adjunct prednisone therapy for patients with community-acquired pneumonia: a multicentre, double-blind, randomised, placebo-controlled trial. Lancet 2015, 385:1511-1518. 
65. Wan YD, Sun TW, Liu ZQ, Zhang SG, Wang LX, Kan QC: Efficacy and Safety of Corticosteroids for Community-Acquired Pneumonia: A Systematic Review and Meta-Analysis. Chest 2016, 149:209-219.

66. Siemieniuk RA, Meade MO, onso-Coello P, Briel M, Evaniew N, Prasad M, Alexander PE, Fei Y, Vandvik PO, Loeb M, Guyatt GH: Corticosteroid Therapy for Patients Hospitalized With Community-Acquired Pneumonia: A Systematic Review and Meta-analysis. Ann.Intern.Med. 2015, Aug 11. doi: 10.7326/M15-0715. [Epub ahead of print].

67. Klapdor B, Ewig S, Pletz MW, Rohde G, Schutte H, Schaberg T, Welte T: Community-acquired pneumonia in younger patients is an entity on its own. Eur.Respir.J. 2012, 39:1156-1161.

68. Kaplan V, Clermont G, Griffin MF, Kasal J, Watson RS, Linde-Zwirble WT, Angus DC: Pneumonia: still the old man's friend? Arch.Intern.Med 2003, 163:317-323.

69. Mortensen EM, Kapoor WN, Chang CC, Fine MJ: Assessment of mortality after long-term follow-up of patients with community-acquired pneumonia. Clin.Infect.Dis. 2003, 37:1617-1624.

70. Johnstone J, Eurich DT, Majumdar SR, Jin Y, Marrie TJ: Long-term morbidity and mortality after hospitalization with community-acquired pneumonia: a population-based cohort study. Medicine (Baltimore) 2008, 87:329-334.

71. Prescott HC, Sjoding MW, Iwashyna TJ: Diagnoses of early and late readmissions after hospitalization for pneumonia. A systematic review. Ann.Am.Thorac.Soc. 2014, 11:1091-1100.

72. Lim WS, Baudouin SV, George RC, Hill AT, Jamieson C, Le J, I, Macfarlane JT, Read RC, Roberts HJ, Levy ML, Wani M, Woodhead MA: BTS guidelines for the management of community acquired pneumonia in adults: update 2009. Thorax 2009, 64 Suppl 3:iii1-55.

73. Kobayashi M, Bennett NM, Gierke R, Almendares O, Moore MR, Whitney CG, Pilishvili T: Intervals Between PCV13 and PPSV23 Vaccines:

Recommendations of the Advisory Committee on Immunization Practices (ACIP). MMWR Morb.Mortal.Wkly.Rep. 2015, 64:944-947.

74. Kim DK, Bridges $\mathrm{CB}$, Harriman $\mathrm{KH}$ : Advisory committee on immunization practices recommended immunization schedule for adults aged 19 years or older--United States, 2015. MMWR Morb.Mortal.Wkly.Rep. 2015, 64:91-92.

75. Centers for Disease Control and Prevention (CDC): Use of 13-valent pneumococcal conjugate vaccine and 23 -valent pneumococcal polysaccharide vaccine for adults with immunocompromising conditions: recommendations of the Advisory Committee on Immunization Practices (ACIP). MMWR Morb Mortal Wkly Rep 2012, 61:816-819. 
Figure 1. Changes in the adaptive immune system:

\section{Humoral Immunity \\ B-lymphocytes}

Increased autoreactive serum

antibodies

Increased IgG and IgA levels

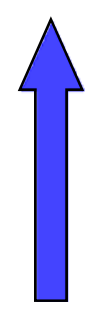

\section{Cellular Immunity \\ T-lymphocytes}

Increased non-functional T cells

Impaired

expansion

and

differentiation into effector cells

Increased proinflammatory cytokines

Decreased naive $T$ cell production

Decreased expression: $\mathrm{CD} 28, \mathrm{CD} 27$

Decreased T cell diversity 
Figure 2. Changes in the innate immune system:

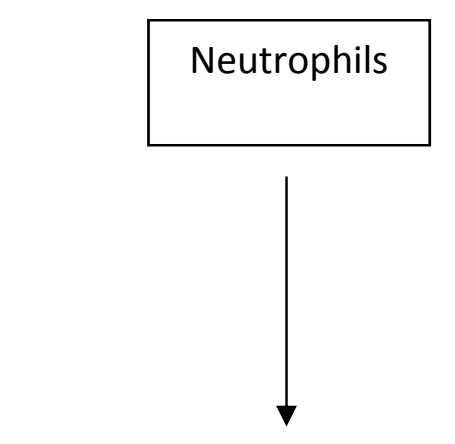

Decreased phagocytic capacity

Decreased bacterial activity
Macrophages

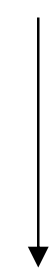

Reduced production of INF

Decreased nitric oxide $/ \mathrm{H}_{2} \mathrm{O}_{2}$

production

Inhibited response to growth

factors
Cytokines/Chemokines

Increased serum levels of IL6 IL1 $b$ and TNF $\alpha$ 
- Falls

- Acute change in functional status

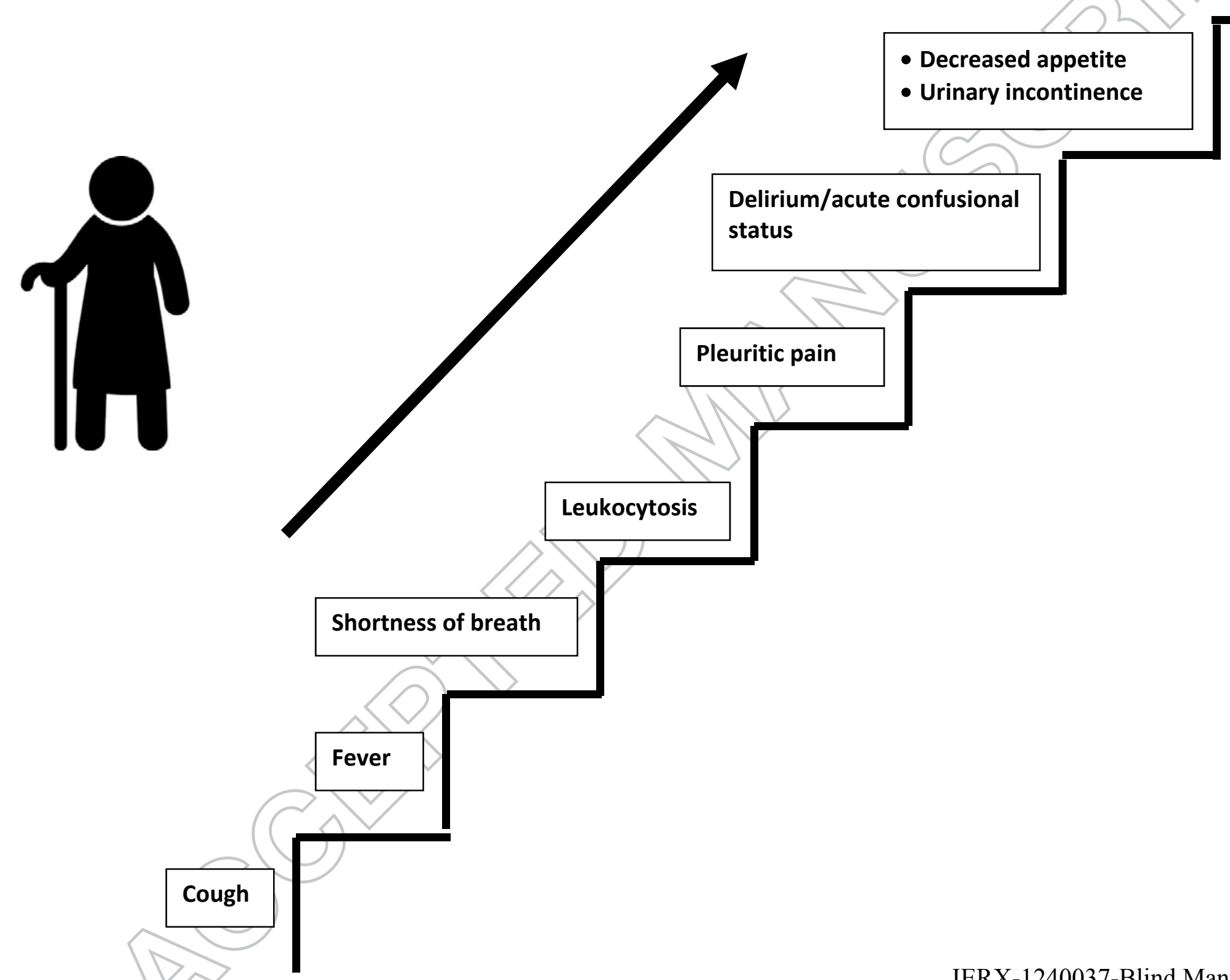




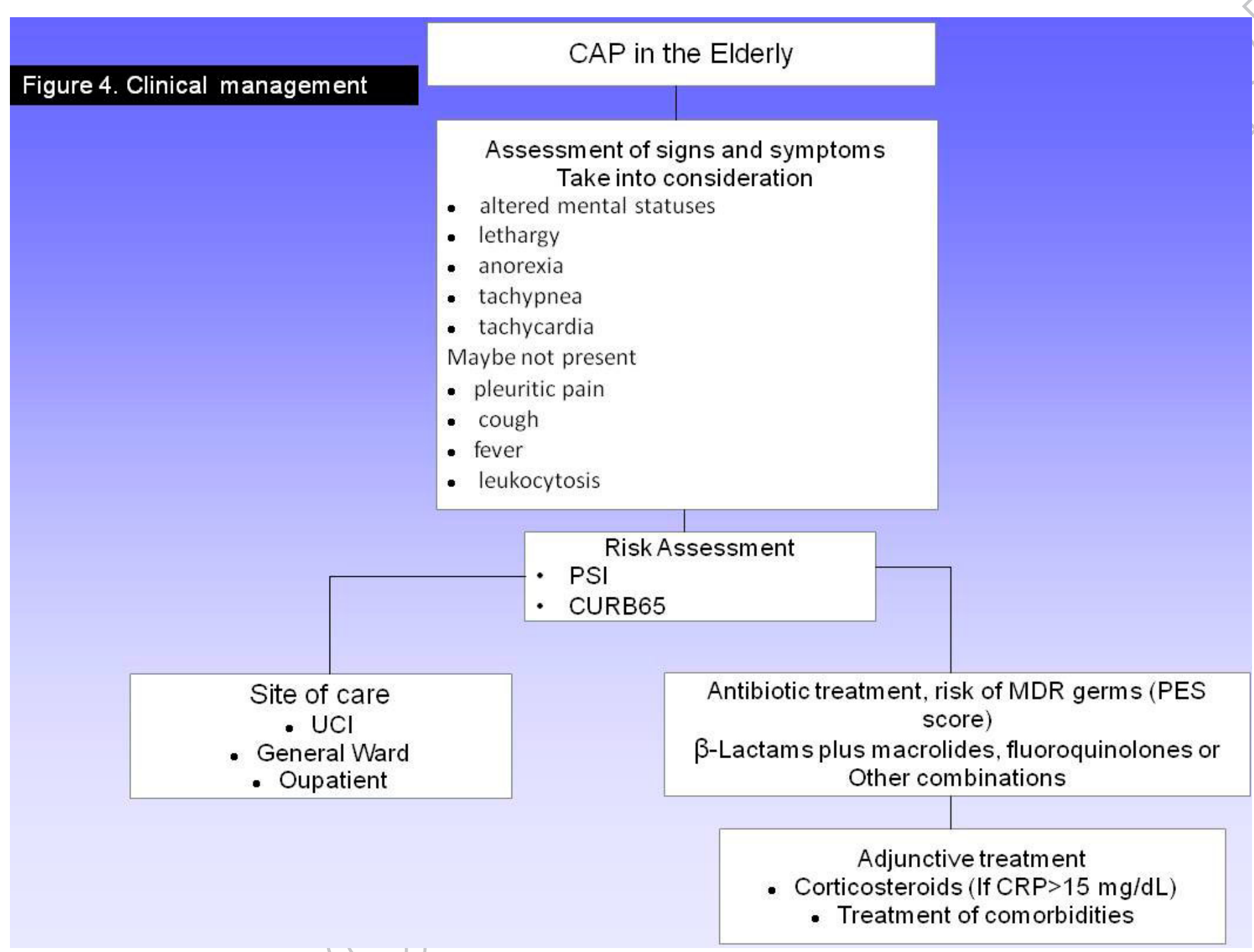

IERX-1240037-Blind Manuscript- Page 32 of 34 
Figure 5. Empirical therapy for CAP in elderly patient

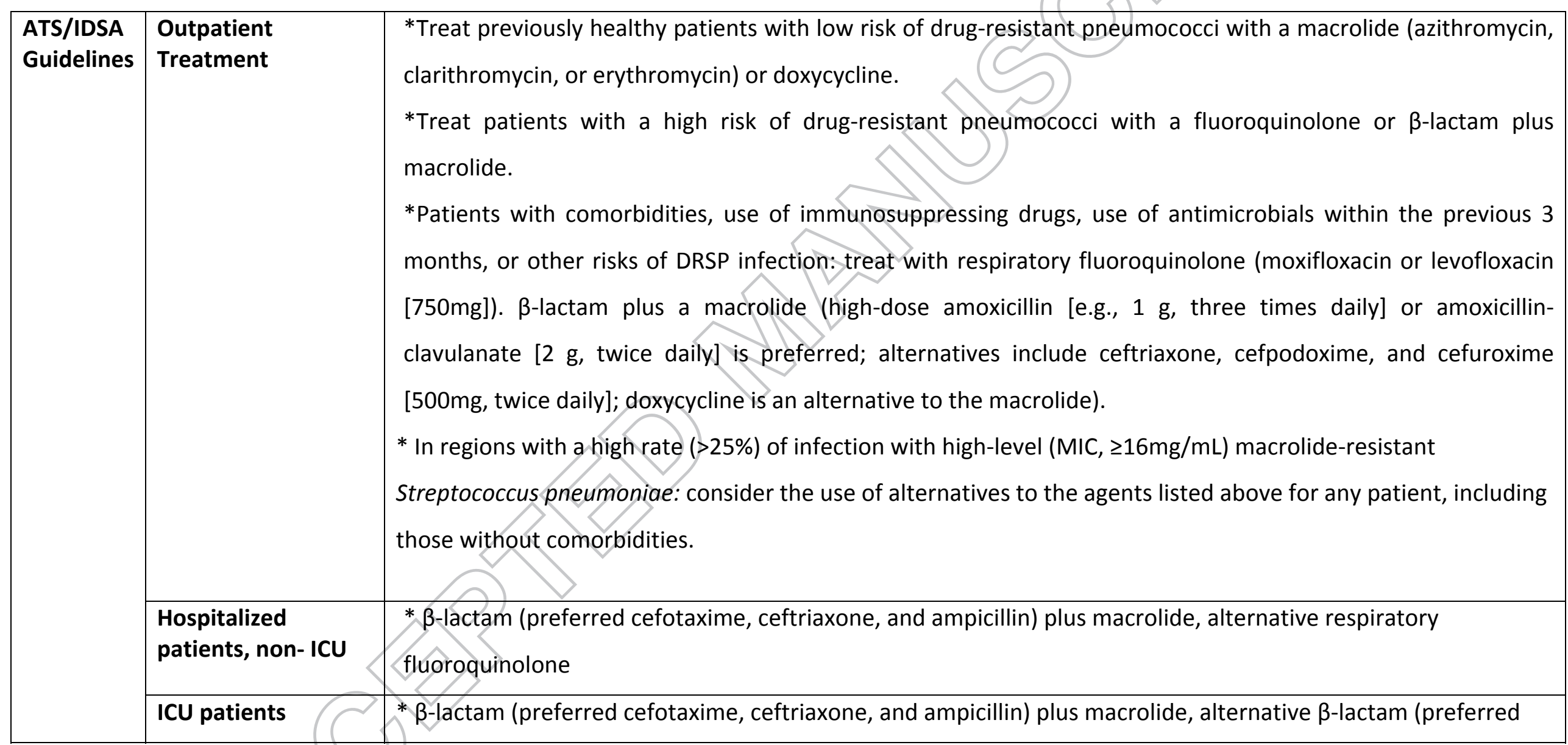




\begin{tabular}{|l|l|}
\hline & $\begin{array}{l}\text { cefotaxime, ceftriaxone, and ampicillin) plus respiratory fluoroquinolone. } \\
\text { *Risk factors for Pseudomonas infection: An antipneumococcal, antipseudomonal, } \beta \text {-lactam plus either } \\
\text { ciprofloxacin or levofloxacin or plus aminoglycoside and azithromycip or plus an aminoglycoside and an } \\
\text { antipneumococcal fluoroquinolone. } \\
\text { *Risk factors for MRSA infection: Vancomycin or linezolid }\end{array}$ \\
\hline \\
Abbreviations: Intensive care unit (ICU); drug resistant $S$ pneumoniae (DRSP); methicillin resistant $S$ aureus (MRSA)
\end{tabular}

Abbreviations: Intensive care unit (ICU); drug resistant $S$ pneumoniae (DRSP); methicillin resistant $S$ aureus (MRSA) 